\title{
The Innovation of Enterprise Management Mode under the Background of Big Data
}

\author{
Kebo Wang \\ School of Tourism \\ Hainan University \\ Haikou, China 570228
}

\begin{abstract}
The advent of the era of big data has brought severe challenges to traditional business management models, and corporate management will undergo tremendous changes. What are the characteristics of enterprise management in the big data environment compared to the traditional enterprise management model? Starting with the basic connotation and characteristics of big data, this paper analyzes the thought change brought by big data. And then, on the basis of the difference between big data innovation and traditional innovation, it constructs the innovation model of enterprise management based on big data, and puts forward the reform model of enterprise management under big data. At the same time, the author believes that the stable large data environment conducive to the development of enterprises cannot be separated from the guidance and support of the government.
\end{abstract}

Keywords-big data; thought change; enterprise management innovation

\section{INTRODUCTION}

In recent years, with the rapid development of computer and information technology, big data is generated and gathered in various industries and fields. The high-speed growth of social data and scientific data are continuously generated and converged together, forming "massive data". Because of the popularity and high-speed development of the network, big data is quietly changing people's way of life. And it will raise great changes of society and thinking. The symbol of the big data age is not to grasp the data. It is to use the data. Through the integration and analysis of the existing data, people can predict the possibility of something in the future, and make more reasonable and scientific decisions to trigger new value growth. The arrival of the big data era brings great impact to the traditional enterprise management mode. The old management mode cannot make the enterprise be in the dominant position in the new era of competition. To mine the useful information from the customer's data and consumption records becomes the key to enhance the enterprise's market competitiveness. The wide application of data flow continuously impels the enterprise to view, adjust and perfect its own management mode. And then, it would adapt to the development of the times [1]. The arrival of the big data era is both an opportunity and a challenge. Therefore, the research on the big data in the aspect of enterprise management is particularly important, which is a topic to be explored urgently by the academic circles.

At present, the research of big data in enterprise management and operation mainly includes: (1) the influence of big data on enterprise management and its application in enterprise management. Liu Ping analyzed the great influence of big data on enterprises from four aspects: management environment, information management, manager and management technology. Chen Guoying pointed out that big data was widely used in enterprise management. And it has been involved in enterprise planning, organization, and the promotion of product innovation. (2) Big data influences business management decision-making. He Jun believes that it will be the data-driven decisionmaking. While improving the decision-maker's decisionmaking ability, it would also put forward higher requirements for decision-making technology. Xu Benzong and others analyzed the new characteristics of enterprise management and decision-making under the big data, sorted out the current research on the frontier topics in the main fields, and proposed that the management and decisionmaking under the big data drive was the research direction in the future [2]. (3) Big data cause enterprise financial management change. Qian Ling believes that the arrival of big data injects new vitality into financial work. The use of big data technology in removing financial barriers, finding useful investment projects, reducing operating costs and other aspects is obvious. Wen Hang and Shen Ying carefully analyzed the influence of big data on the accounting quality of enterprises and put forward some suggestions to improve the accounting quality of enterprises.

To sum up, the arrival of big data will bring severe challenges to the enterprise management model. The current research on big data in the field of enterprise management is only preliminary exploration. It has not yet formed a systematic research system. In this paper, based on the background of big data era, the goal is to realize enterprise innovation management. Based on the distinct characteristics of big data, we should combine with the reformed enterprise management thinking. The enterprise management innovation model based on big data background is constructed on the basis of comparing the traditional enterprise management innovation with the enterprise management innovation under big data. Finally, it analyzes 
the positive role of the government in promoting the development of big data. And then, it would create conditions for the rapid development of big data.

\section{BASIC OVERVIEW OF BIG DATA}

\section{A. Definition of Big Data}

In fact, big data refers to a large number of information data. That is, by means of Internet, simple information data can be combined, collated and analyzed to form a diversified information data process.

\section{B. Basic Features of Big Data}

Big data is a kind of information data which has good development status and has important influence on all walks of life. Compared with other information data, big data has the characteristics of large amount of information, fast updating speed and high value. Specific features are as follows:

1) Large quantities of information: Large amount of information is one of the most fundamental features and the most significant features of big data. The data information which generally covers less information cannot be called big data. From the definition of big data, we can see that big data is the processing, analysis and integration of all kinds of information, which generally covers all walks of life. The number of which is astonishing [3][4][5]. According to the calculation of some experts, if general big data were stored on standard discs, the number of discs needed could be more than a dozen circles around the earth and the moon. And that data would continue to grow. It can be seen that with the development of technology and the progress of society, the era of big data has come to all walks of life and gradually penetrated into all walks of life, providing important information resources for the development of the industry.

2) High-speed updates: Dependence on the existence and development of the Internet determines the speed of updating big data. The development and updating of the Internet is also taking place at an unpredictable speed. The development and updating of the Internet must bring astonishing updates to the information. In the end, the big data also presents the characteristics of fast update speed. For example, the data information of a certain industry has been updated and increased. After the Internet receives these new information, the information of big data also must be updated and increased accordingly. Perhaps somewhat inadvertently, there will be startling differences in big data information over an hour. This also decides that all walks of life must maintain a high degree of sensitivity. It must tap favorable important information and make use of it as soon as possible. Then, it would promote the all-round development of the industry [6].

3) High value: The amount of information contained in the big data is enough and the update speed is fast. All walks of life using the big data can get a lot of valuable results and information through the big data. For example, in scientific research, big data can provide effective information to facilitate the scientific research, forming their own scientific research value. In the aspect of promoting economic development, big data shows its own economic value by improving the speed, efficiency and quality of work or research. In the aspect of society, the value of big data is self-evident. The applied value and life value that it creates for the society cannot be ignored [7][8][9][10].

\section{PRoblems Existing IN ENTERPRISE MANAGEMENT Mode IN THE BIG DATA AGE}

With the advent of the big data age, much business management is also helped by big data. It has been well developed. Due to the short time of the big data age, the influence of some traditional concepts and models and other various reasons, there are still some important problems in the enterprise management model under the big data age which deserve our attention.

\section{A. Corporate Leaders Do not Pay Enough Attention to Big Data}

The arrival of the big data era makes many enterprises' management more orderly. Viewing from the whole, the big data cannot really be integrated into the management of the enterprise. The enterprise leaders do not pay enough attention to the big data, and cannot correctly recognize the huge value of the big data. And they are affected by the traditional concept. The enterprise did not carry out in-depth research on the big data. They still use the traditional management model. As you know, the value of the traditional management mode in the course of enterprise management is very limited. Only simply through a single channel to collect the required information data cannot guarantee the integrity and reference value of these information data. Under the background of big data era, it has gradually highlighted the drawbacks. It cannot really promote the effective management of enterprises.

\section{B. Enterprise Marketing Methods Are not Advanced}

In the context of big data, marketing is no longer a simple transaction process under the planned economy. It should combine service with enterprise culture and prestige organically in the marketing process. Also, it should sell to consumers and some potential customers in the form of packaging. And ultimately, it would realize the purpose of spreading enterprise culture, improving enterprise economic efficiency and promoting enterprise development. However, from the current point of view, many enterprises have not really reformed their own marketing methods, or even did not correctly recognize the development of marketing in the big data era. They still adhere to the traditional marketing means. In the era of big data, the traditional marketing methods cannot adapt to the development of the times. It would hinder the development of enterprises. 


\section{Enterprise Data Security Issues Are Prominent}

Big data not only brings convenience to enterprises, but also brings some information security hazards, especially under the current state of popularization of computer network. Whether the impact of natural disasters or the improper operation of staff, or hackers or virus invasion, it is possible to bring huge problems to the enterprise information. As we all know, the information data and other related to the enterprise archives, development data, the use of information or important business secrets, once big data security incidents occur, it may bring irreversible harm to the enterprise. In recent years, a lot of business secrets leak is reported from time to time, which is the prominent performance of enterprise data security in the age of big data.

\section{Enterprises Lack Professional Talents to Make Data Analysis and Processing}

Big data exists and develops through internet and computer. Human is still the main executor of enterprise data analysis and processing. Data information processing is technical and complicated work. It needs professional knowledge to accomplish it well. However, at this stage, many enterprises in China still lack some outstanding professionals to make data analysis and processing. They often transfer personnel from other positions to temporarily participate in the data analysis and processing work. In order to save costs, they would recruit some slightly computersavvy staff. All of these make the efficiency and quality of enterprise data processing not high. And they have certain negative impacts on the development of enterprises.

\section{ENTERPRISE MANAGEMENT INNOVATION MODEL UNDER THE BACKGROUND OF BIG DATA}

\section{A. Comparison of Enterprise Management Innovation in Traditional mode and that of Big Data Mode}

The traditional mode is an exploratory innovation based on the specific problem of enterprise practice management and driven by the problem. Based on the combination of qualitative analysis, this paper explores the ways to solve the problems. And then, it would realize the innovation of enterprise management, starting from the system management and humanized management and utilizing the organizational knowledge and expert wisdom. Under the big data environment, the innovation environment and the condition is complex and diverse. There will have many possible innovation choices and the realization enterprise management innovation method and path. It is undoubted that the change of the environment and condition of the enterprise will influence the choice of the management method and the realization of the final result. It is like "fishing in the pond" in the past. And it is "fishing in the sea" now. Therefore, with the changes of external environment, there are many essential differences between enterprise management innovation in big data environment and traditional mode, as shown in "Table I".

TABLE I. COMPARISON OF ENTERPRISE MANAGEMENT INNOVATION IN TRADITIONAL MOdE AND THAT OF BIG DATA MODE

\begin{tabular}{|l|l|l|l|l|l|}
\hline $\begin{array}{l}\text { innovation } \\
\text { model }\end{array}$ & driving factor & $\begin{array}{l}\text { environment and } \\
\text { condition }\end{array}$ & $\begin{array}{l}\text { innovative } \\
\text { approach }\end{array}$ & $\begin{array}{l}\text { Innovation } \\
\text { method }\end{array}$ & $\begin{array}{l}\text { critical } \\
\text { factors }\end{array}$ \\
\hline $\begin{array}{l}\text { Traditional } \\
\text { enterprise } \\
\text { management } \\
\text { innovation }\end{array}$ & $\begin{array}{l}\text { Problem- } \\
\text { driven }\end{array}$ & $\begin{array}{l}\text { Voluntary in the } \\
\text { organization } \\
\text { from top to } \\
\text { bottom }\end{array}$ & $\begin{array}{l}\text { Delphi method, } \\
\text { decision tree } \\
\text { method }\end{array}$ & expert experience \\
\hline $\begin{array}{l}\text { Enterprise } \\
\text { management } \\
\text { based on big } \\
\text { data }\end{array}$ & $\begin{array}{l}\text { innovation } \\
\text { problems, } \\
\text { data-driven }\end{array}$ & $\begin{array}{l}\text { big data in } \\
\text { organizational } \\
\text { ecology }\end{array}$ & $\begin{array}{l}\text { from top to } \\
\text { bottom, from } \\
\text { bottom to top, } \\
\text { Network } \\
\text { synergy }\end{array}$ & $\begin{array}{l}\text { cloud } \\
\text { computing, } \\
\text { DMining), statistic } \\
\text { analysis }\end{array}$ & $\begin{array}{l}\text { Availability of data, } \\
\text { Data } \\
\text { results } \\
\text { interpretation } \\
\text { accuracy }\end{array}$ \\
\hline
\end{tabular}

\section{B. Enterprise Management Innovation in the Background} of Big Data

Big data is the core element of enterprise management innovation. And the process of data processing and analysis is the key to solve the big data problem. Researches in related fields show that there is a relationship between data processing, analysis process and innovation process. Therefore, around the data problem in the innovation process, this paper establishes the enterprise management innovation model under the big data environment (as shown in "Fig. 1"). 


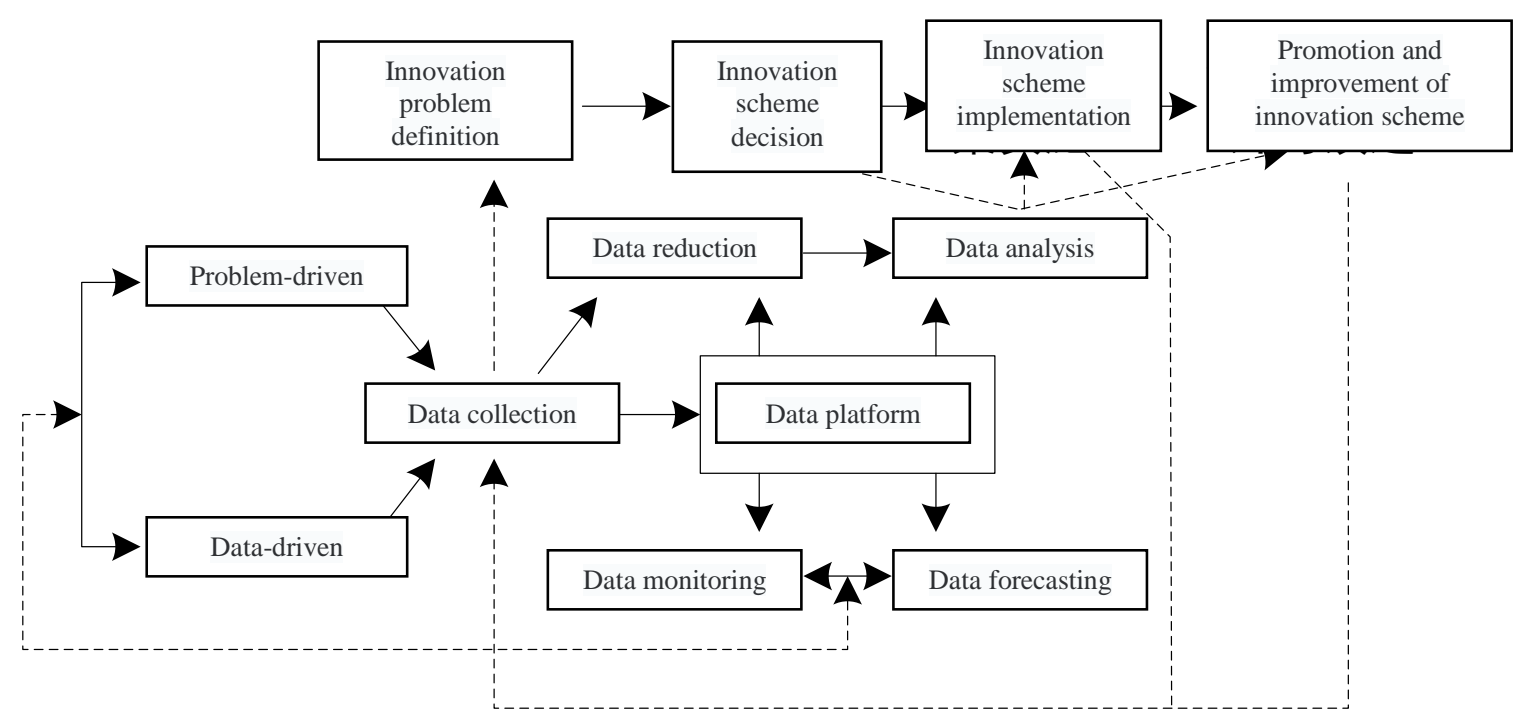

Fig. 1. Enterprise management innovation model under the background of big data.

1) Data access and the formation of data platforms: In the big data era, the enterprise data platform plays an important role in the enterprise. It undertakes the function of data collection, processing, analysis, monitoring and prediction in the production and operation of the enterprise. Innovative management activities in enterprises are often driven by problems or data (or problems found in the process of data monitoring and forecasting at ordinary times).

2) Definition of innovation issues and scheme decisionmaking: After finding the problem, the enterprise should first determine whether it is necessary to carry on the enterprise management innovation. The key problem involved in this decision is the collection and acquisition of data. With the advanced computer and information technology, the enterprises can gather relevant data and assess whether innovation is needed and whether it is possible to do so. If necessary, first of all, we must define the problem of innovation. First, it should roughly determine the current innovation areas and scope. Second, with the help of preliminary qualitative data analysis, it should make a specific explanation on the innovation problems. On the basis of the definition of innovative problems, the deep-seated information of data is mined by various data analysis techniques. The semi-structured and non-structured data are pre-sorted and refined to be transformed into structured data which can be identified and analyzed by the database. Based on the results of data analysis, the feasibility and expected effect of the proposed alternatives are re-verified. And then, we could select the satisfactory innovative alternatives.

3) Dynamic data and the implementation of innovation scheme: In the course of the implementation of the innovation plan, they are constantly accumulating implementation data and performance data. These generated real-time data collection, collation and analysis would be "data source" processed by the data sharing platform. Through the feedback analysis of the real-time data, we can correct the deviations in the process of the implementation of the enterprise innovation plan, monitor the innovation plan uninterruptedly and optimize it in real time. Then, it would ensure the successful achievement of the innovation goal. This can ensure that the whole process from the implementation to the end of the innovation is in a process with real-time feedback and continuous improvement. It is not the traditional static process. Thereby, it would greatly improve the probability of success of the innovation scheme.

4) Upgrading of real-time data and innovation schemes: In the whole process of the implementation of the innovation scheme in the big data environment, the result of the data analysis is tested in real-time. And the adjustment and correction are made according to the real-time internal and external environment faced by the enterprise. It is to carry out the innovation scheme smoothly. In this way, we can avoid a series of water and soil disobedience caused by the different internal and external environment of enterprises when introducing other referential innovation schemes. In addition, it can collect and analyze real-time data in the process of the implementation of the innovation scheme, and revise the original innovation management scheme through the feedback of the operation data, and achieve the effect of upgrading the innovation scheme.

\section{INNOVATIVE COUNTERMEASURES OF ENTERPRISE MANAGEMENT Mode IN THE Big DATA AGE}

This paper analyzes the problems existing in the enterprise management model in the era of big data. Combining the characteristics of the big data era, we should use the most scientific spirit, the most rigorous attitude, and the most professional knowledge to continuously make the 
exploration in practice. And then, we could make innovative research in the enterprise management.

\section{A. Corporate Leaders Should Accelerate the Change of Concept and Pay Attention to the Use of Big Data}

In the context of the era of big data, the traditional management model of enterprises has gradually highlighted drawbacks. This requires that business leaders must accelerate the change of concepts, correctly understand the connotation and commercial value of big data, and make full use of big data. First, corporate leaders should increase their investment in big data research, conduct in-depth research on big data, collect, sort out, and analyze big data that are conducive to the development of the enterprise. Second, corporate leaders should pay attention to the social network of employees. And enterprises data can be circulated within the company more efficiently. It would promote the efficient management of the enterprise. Third, the enterprise should carry out appropriate reform of the traditional management model. When it is necessary, we can even completely abandon it. The management mode that conforms to the development of the age that can promote enterprise development is a good model.

\section{B. Enterprises Should Improve Marketing Methods}

Since big data has updated the connotation of marketing, companies can no longer continue to use the past marketing methods. They should make appropriate improvements in marketing tools. In the process of marketing or cooperating with other companies, the company's culture, ideas, credibility and services must be properly packaged and traded. Ultimately, the products or services traded are no longer just products or services. They also represent the corporate culture, concepts and credibility behind products and services. Namely, it is brand marketing. In order to better marketing, companies should continue to increase their own brand value. They can make the demonstration to people through publicity and practical actions. Ultimately, the enterprise marketing management keeps up with the development of the big data era.

\section{Enterprises Should Intensify Information Security Management}

In order to ensure the security of enterprise data information in the era of big data, enterprises should increase the intensity of information security management. First of all, companies should do a good job of preventing natural disasters in advance, such as placing computers in locations that are less vulnerable to flooding and lightning strikes. Secondly, enterprises should strengthen the supervision of information management personnel, and prevent them from giving out corporate secrets for the sake of their own interests. Third, companies should carry out anti-virus and hacking measures on computers, such as installing firewalls and anti-virus software, virus detection on U disk and CDROM. It is also necessary to make a complete backup of some important data information. It would prevent the loss of information due to accidents or planned information theft.
And eventually, it would lead to the occurrence of harming the interests of the company.

\section{Enterprises Should Introduce and Train Excellent Personnel to Make Information Analysis and Processing}

In the context of the era of big data, enterprises must pay more attention to the cultivation of information analysis and processing personnel. First of all, it requires companies to increase capital investment in talents. The companies should introduce excellent information analysis and processing specialists, and recruit employees with strong professional background and rich work experience. Of course, in addition to the introduction of excellent talents, companies need to increase the training of information analysis and processing personnel. They can hire authoritative experts to teach their employees on a regular basis. They can also arrange the employees to participate in professional seminars or seminars outside the company. Through the systematic study, the employees would constantly enrich themselves, improve one's own professional quality, and make contribution for the development of the enterprise.

\section{CONCLUSION}

Big data is used in various fields, and the links with companies are inseparable. At the present and in the future, the development of enterprises will mainly rely on the use of data. The development of enterprises has been more difficult in the era of big data. The structured and unstructured diversified data processing capabilities are weak. They have brought great impacts and challenges on enterprise management. However, it is necessary to maintain the cultivation of data processing talents and innovative management methods. Only by doing so can we ensure that we can stand up against the wind in harsh market conditions and stand up to the impact of the times.

\section{REFERENCES}

[1] Wen Hang, Shen Ying. The impact of big data era on the quality of business accounting information $[\mathrm{J}]$. Science and Technology Outlook. 2015(22). 温航,沈英.大数据时代对企业会计信息质量的 影响[J].科技展望.2015(22).

[2] Liu Ping. The impact of big data era on business management [J]. Chinese and Foreign Entrepreneurs. 2015(18). 刘平.大数据时代对于 企业管理的影响[J].中外企业家.2015(18).

[3] Chen Guoying. Application of big data in business management [J]. Finance and Economics (Academic Edition). 2015(11). 陈国营.大数 据在企业管理中的应用[J].财经界(学术版).2015(11).

[4] Qian Ling.The influence of the arrival of big data era on corporate financial work [J].Geology of Anhui. 2015(01). 钱玲. 大数据时代的 到来对企业财务工作的影响[J].安徽地质.2015(01).

[5] Wei Junru, Wang Yuanliang. The innovation of enterprise management mode in big data era [J]. Information System Engineering. 2014(11). 卫俊儒,王元亮. 大数据时代下的企业管理模 式的创新探析[J].信息系统工程.2014(11).

[6] Feng Mei. Challenges and innovations faced by enterprise management in big data era [J]. Modern Enterprise. 2014 (11).奉梅. 大数据时代下企业管理所面临的挑战与创新 [J]. 现代企 业.2014(11).

[7] Xu Zongben, Feng Zhiyan, Guo Xunhua, et al. Big data driven management and decision-making frontier topics [J]. Management 
World. 2014 (11). 徐宗本, 冯芷艳, 郭迅华, 等. 大数据驱动的管理与 决策前沿课题[J].管理世界.2014(11).

[8] Zhu Lina. Research on innovation of enterprise management mode in the context of big data[J]. Journal of Suzhou Education Institute. 2017(04). 朱丽娜.大数据背景下企业管理模式的创新研究[J].宿州 教育学院学报.2017(04).

[9] Wang Bo. Research on innovation strategy of enterprise management model under the background of big data era $[\mathrm{J}]$. Modern Economic Information. 2017(13). 王博. 大数据时代背景下企业管理模式创新 策略探究[J].现代经济信息.2017(13).

[10] Qiu Hui. Research on innovation of enterprise management model in the big data era [J]. Chinese and Foreign Entrepreneurs. 2017(18). 邱 慧. 大数据时代下企业管理模式创新研究[J].中外企业家.2017(18). 